\title{
CSR AND SUSTAINABILITY REPORTING IN INDIA: THE WAY FORWARD
}

\author{
SATBIR YADAV ${ }^{1} \&$ Dr. SUNIL BUDHIRAJA ${ }^{2}$ \\ ${ }^{I}$ Research Scholar, Lovely Professional University, Phagwara, Punjab, India \\ ${ }^{2}$ Associate Professor and HOD, Department of Human Resource Management, Mittal School of Business,
}

Lovely Professional University, Phagwara, Jalandhar (Punjab), India

\begin{abstract}
For over a quarter century, the term 'Sustainability Development' (SD) has been at the forefront of all discussions and decisions on corporate strategy for growth \& development in an organization and thus, the importance of greater transparency \& integrity in Sustainability Reporting (SR) under the overall Corporate Reporting (CR). Reporting - both financial \& non-financial, is not only essential for internal evaluation but also for the external valuation. Reporting on account of Corporate Social Responsibility (CSR) or Sustainability Development initiatives in India is also mandated by law under Companies Act, 2013 for certain specified companies besides being having a moral obligation for voluntary disclosure to all stakeholders including the society at large.

Through this paper, an effort is made to draw the link between Sustainability Reporting (SR) or Corporate Social Disclosures (CSD) and Corporate Reporting (CR) and their relevance to overall Corporate Governance (CG) by exploring the concepts and their interlinks beside highlighting the need \& importance for both voluntary disclosures and mandatory reporting of CSR activities \& expenditures under Companies Act, 2013. An intensive review of literature on relevant aspects of the topic has been undertaken and an analysis made in the context of both national \& international companies operating in the country.

The methodology adopted for the paper involve Literature Review Analysis (LRA).

The objective of this research rather review is to convey the concerns of all stakeholders, including the society within which an enterprise exists or operate, to one of the most important players of the game (read financial expert) through simple explanation of the concepts and rationale behind CSR \& SD so as "to increase the depth and scale of the commitment of Indian Companies towards Sustainability Reporting” (Kumar \& Devi, 2015)

KEYWORDS: Corporate Social Responsibility (CSR), Corporate Governance (CG), Corporate Reporting (CR), Sustainability Reporting (SR), Integrated Reporting (IR), Companies Act \& 2013
\end{abstract}

Received: May 14, 2019; Accepted: Jun 03, 2019; Published: Jun 29, 2019; Paper Id.: IJHRMRAUG20199

\section{INTRODUCTION}

It is said, "what gets measured get managed" and to extend the saying, we can say that what gets measured and managed well, can be reported correctly as well which, in turn, help companies in many ways - to improve business efficiency, identify opportunities \& risks, learn the art of competitive differentiation, attract \& keep employees engaged (hire \& retain) and ensure the reputation management for the least. To achieve all these and much more, it is the corporate governance which acts as an umbrella of protection from heat \& rain, provided there is no swirling wind upward to blow it off as 
"Every profession bears the responsibility to understand the circumstances that enable its existence."

- Robert Gutman

Corporate Governance - the 'umbrella for the business entity' (as authors view it), acts like a protective shield but does not shield the unprotected. Corporate governance consists of policies \& processes, rules \& regulations, Acts \& Laws of the land, and institutions affecting the way a corporate is governed. It also includes the relationships amongst stakeholders involved and the overall goals of the corporate. In addition to the Management, other main stakeholders in a corporate are the Board of Directors and the principal - shareholders. Nevertheless, the others like its employees \& customers, creditors \& lenders, auditors \& regulators, suppliers \& partners and the society in which it operate, are also equally important stakeholders. As a process, corporate governance is an activity which essentially involves balancing the interests of these stakeholders. Corporate Governance actually provides the framework to attain a company's objectives and thus practically includes every aspect of management, from planning and controlling to measurement of performance - both financial and non- financial beside the corporate reporting - the theme of our deliberation, in context of Sustainability Development through Corporate Social Responsibility.

Corporate Social Responsibility: CSR, to say the least, is a kind of self-regulation integrated into the business strategy or a model. CSR as a process and practice can be described as the dedication by corporate towards both social and economic well-being of the society. CSR is a kind of moral obligation on the part of corporate to undertake such initiatives which results in the betterment of society. In the past, CSR in India revolved around charity and donations but today it has gone beyond philanthropic sphere. It is approached in a rather organized and systematic manner duly integrated with the business strategy for achieving the corporate goal of being responsible to all its stakeholders including the society in which operate and rather owe their existence to. Most of the companies have their dedicated CSR groups or teams to plan and execute such activities with the same sense of urgency and responsibility as their core concerns and one of the main objectives is to maximize the corporate's overall impact on its immediate community and stakeholders including the society at large.

Corporate Social Responsibility (CSR) today is more than what corporates are ordinarily required by regulatory authorities as legal compliance. Today, there is high awareness amongst all concerned for the need of corporate responsibility, sustainable development and the transparency in its reporting - both 'Financial' and 'Non-Financial', leading to a concerted effort on the part of every organisation to look at 'sustainable development' as a goalpost. CSR, in essence, is the strategic integration of a corporate's social, economic, and environmental goals within its business operations i.e. internally and externally, by way of interactions with and involvement of its stakeholders.

Sustainability Reporting: The report published by an organization or a company on its social, economic, and environmental impacts caused by its day-to-day business activities is termed as Sustainability Report or Reporting (SR). It helps company to gauge the impacts of their activities on various issues related to sustainability and thus, need to be more transparent in highlighting risks and opportunities it may face. Also, a sustainability report acts like a mirror for values and model of governance an organization adopts.

Sustainability reporting can help organizations to measure, understand and communicate their economic, environmental, and social - Triple-Bottom-Line and governance performance. It enables an organisation to set goals, and 
manage change more effectively. A sustainability report is the key platform for communicating sustainability performance and impacts - whether positive or negative.

The terms like Non-Financial Reporting (NFR); Triple Bottom Line (TBL) Reporting, and Corporate Social Responsibility (CSR) Reporting are considered synonymous to Sustainability Reporting (SR). Also, it is an integral part of IR - Integral Reporting, a recent development which provides the combined analysis of financial and non-financial performance of an organisation.

"Corporate responsibility reporting is - or should be - an essential business management tool. It is not - or should not be - something produced simply to mollify potential critics and polish the corporate halo."

-Yvo de Boer (KPMG, 2013)

\section{RESEARCH OBJECTIVES AND METHODOLOGY}

- To analyze the concepts of Corporate Social Responsibility (CSR) and Sustainability Reporting (SR) in context with Corporate Governance \& Reporting.

- To evaluate the existing scenario of CSR and status of Sustainability Reporting in the country.

- To highlight the need and importance of Sustainability Disclosures under the overall Corporate or Integrated Reporting.

The study is based on qualitative exploratory research using secondary data and information available on Proquest and Google scholar database.

\section{LITERATURE REVIEW}

Corporate Social Responsibility: The modern idea or concept of CSR (Corporate Social Responsibility) can be attributed to Howard Bowen who formally coined the term in 1953 in the publication "Social Responsibilities of Businessmen". He defined it as "the obligations of businessmen to pursue those policies, to make those decisions, or to follow those lines of action which are desirable in terms of the objectives and values of our society" (Howard, 1953). But the attention of academicians was drawn to the concept only during 1980's and 90's when it was discussed and debated upon within their circles before being applied in an industry or corporate. Shell was the first company which implemented CSR in 1998 (Fauset, 2006, Corporate Watch Report).

Almost all countries have contributed to the development of literature on CSR but it was practically applied initially by developed countries, especially the United States and some of the European nations. CSR, as a concept, has evolved itself into an all-encompassing field and interpreted differently by various authors and practitioners from their own perspectives. "A number of concepts and issues are subsumed under the heading of CSR, including human rights, environmental perspective, diversity management, environmental sustainability and philanthropy" (Amaeshi et.al., 2006). The concept of CSR is thus not only complex in nature but also varied in applicability.

"Corporate social responsibility has assumed more than fifty different names across the world but the central theme in all of them has to do with the idea of a business being responsible beyond the boundaries of its brick-and-mortar structure to affecting the lives of other stakeholders, such as the local community and society at large" (Visser 2006). The definition given by the World Bank clearly conveys this idea when it defined CSR as "the commitment of business to 
contribute to sustainable economic development, working with employees, their families, the local community and society at large to improve their quality of life in ways that are both good for business and good for development". CSR, according to the definition, is a sustainable, profitable and long-term business proposition not only for the business concern (corporate) but also for all involved - its stakeholders. Consequently, a company shall stand to gain in more than one way like "increased productivity, reduced transactional costs, and clientele attraction, in addition to having a good corporate image through its CSR activities" (Dartey-Baah, et.al., 2015). Definition put forward by World Bank emphasizes on aspect of "social investments in people connected to the business, contributing to sustainable economic development while working with the local community". CSR, as per this definition, can serve as a means for development of the community involved and the nation. For this idea to be implemented with a meaningful contribution to the development of the society and the nation, it is necessary rather prerequisite that immediate needs of society in which corporate operates must be aligned with its CSR activities.

The academicians and researchers in the subject of CSR have discussed and debated its nature for long. One of the most prominent among the latter is Carroll. According to Carroll (2016), CSR have four dimensions - "economic, legal, ethical, and philanthropic/discretionary acts"- with their priority being in decreasing order, as he defined CSR, involving "the conduct of business such that it is economically profitable, law abiding, ethical and socially responsible" (Visser 2006).

"A fundamental economic understanding of CSR is emerging".

- Kitzmueller and Shimshack, (2012)

\section{CSR in India - The Legacy}

Corporate Social Responsibility (CSR) in India has been in existence since the beginning of the trade and business. We have a rich history of CSR in the form of charity \& philanthropy. The involvement of businessmen in social cause - especially during the time of natural calamities like floods \& famine, constructions of wells (Piyao) and inns (Sarai) on main roads leading to towns \& cities having centers of trade, has been existing since long. During the initial phase, CSR was seen and found in the form of social duty or charity. Its origin can in fact be traced to our religious scriptures and teaching as we find mention of terms like Dharamdaa in Hinduism, Zakaat in Islam and Dashaand in Sikhism, all of which essentially means that people with wealth \& resources must contribute to the welfare of poor strata of society. Kautilya, during Mauryan period, also emphasized upon business with ethics and social responsibility or conduct. The idea or concept of modern day CSR has evolved and developed in the country through different ages and phases. Social and environmental issues have been deeply associated with the business in India. Business as a source of creation of wealth has been contributing for the welfare of the society. Corporate philanthropy has been a part of Indian tradition and the social welfare an integral part of Indian business since long. The industrial welfare has also been in practice since late 1800s. During 1900s, socially responsible business practices took different forms like corporate charity or donations, employee and their families' welfare, promoting social causes and religious conduct/events. By 1950s, CSR was considered obligatory on the part of the business.

Initially, there was no record or documentation of CSR initiatives \& activities in the country. The desire to contribute towards social activities and improvement of immediate environment has since then been growing globally. Also, it has been observed that companies which genuinely commit themselves to the principles and practices socially 
acceptable \& responsible behaviour are increasingly preferred over the others by their own employees as an employer and the public for its goods and services leading to a win-win situation for all. This has probably led to the modern concept of CSR and subsequently to Sustainable Development. According to the World Business Council for Social Development (WBCSD), "Corporate Social Responsibility is the continuing commitment by business to behave ethically and contribute to economic development while improving the quality of life of the work force and their families as well as of the local community and society at large".

CSR, as discussed earlier, as an idea or a concept is not new to India or its business. The sphere of business responsibilities has been perceived to encompass both financial and non-financial dimensions (Kulkarni, 2014) in India and has been known for philanthropic activities as a socially responsible business. The great Indian epic, Bhagavad-Gita lays emphasis on righteous doing. The concept of corporate social responsibility exists in India since the period of Vedas \& Puranas and has travelled through the terrain of trusteeship and social mode during pre-liberalization. Post liberalization, India has witnessed transformation in CSR performance and its reporting.

Since the very inception, the corporate, both under private and public sectors like Tatas, Birlas, Bajajs, Singhanias, IOCL, MUL, and many others have closely involved themselves in social upliftment and community development by undertaking long-term or sustained initiatives. A large number of organisations have been helping the society in their own way. However, the main objective of CSR now-a-days is to ensure maximum benefit to all involved i.e. to optimize the overall impact of firm's activities on its all stakeholders including the society. The policies and practices related to CSR are being integrated by most of the companies in their entire value chain i.e. their business operations and processes are comprehensively integrated with CSR policies and programmes. For most of the corporate, CSR is not just an activity to be undertaken on the sideline of its core business resulting into an indirect expense but an extremely important task duly assigned and strategically integrated with not just its business activity of the day but increasingly with the very vision \& mission, to build their brand and protect the reputation or goodwill leading to enhanced employees' performance and increased business competitiveness. Now-a-days, companies have dedicated CSR Cell, if not a full-fledged department, equipped with specialized teams to formulate or develop strategies, policies and goals for CSR programmes beside setting aside the required budget to support and implement them. These CSR programmes are in line with social philosophy or beliefs and objective of the enterprise, having been clearly defined and aligned with the core business. The CSR programs are implemented by engaging their own employees as they act as key link for the success of the same. CSR initiatives and programs involve whole range of activities like community development, improvement in the areas of sanitation, healthcare, education and environment. The companies in the country have been very careful and specific in taking up various CSR activities by way of aligning \& integrating these with their overall business domain.

\section{CSR - Disclosure \& Reporting}

"A strong disclosure regime can help to attract capital and maintain confidence in the capital markets. By contrast, weak disclosure and non-transparent practices can contribute to unethical behaviour and to a loss of market integrity at great cost, not just to the company and its shareholders but also to the economy as a whole".

OECD Principles of Corporate Governance (2004) 
Reporting - financial and non-financial, has been an integral part of the corporate's life for long. According to the OECD Principles of Corporate Governance - an established and recognised international benchmark, "disclosure should include, but not be limited to, material information on a company's:

- $\quad$ financial and operating results;

- $\quad$ objectives; and

- foreseeable risk factors".

These principles emphasizes on the high quality standards to be maintained in accounting and the financial \& nonfinancial disclosure while reporting. To achieve this, an independent audit machinery must be in place to conduct the audit so as to ensure all material aspects have been duly accounted or properly represented.

As the concept of sustainable development has gained momentum over the years during last two decades, it has become all the more important now-a-days as all stakeholders including investors and consumers, are not only interested in talking or discussing about but also getting more demanding in seeking information on company's sustainability front i.e. its performance in social and environmental areas. Though India lags behind many countries in the area of development of sustainability disclosure or CSR reporting yet, it has started leaving its mark of both desire and necessity at Board level. In India, presently only financial accounting of various operations of an organization's performance is a statutory requirement and not the non-financial or financial accounting of the sustainability field as it is a voluntary activity except for the specified firms covered by relevant clause under Section 135 of Companies Act, 2013. Irrespective of its being voluntary or mandatory, in this era of 'Sustainable Development', a good sustainability report is a pre-requisite for the sustained investors' interests and customers' continuum beside being essential for enhanced transparency and accountability of corporate reporting which, in turn, leads to heightened faith \& trust in the management and Board of Directors.

Corporate Sustainability Reporting (CSR) or Corporate Social Disclosure (CSD) as commonly called is essentially a graphical representation of impact of social activities of the firm on society as Branco and Rodrigues (2006) states that "the business activities impact on various components of the society such as the environment, employee, consumer and local community". To say in other words, corporate social reporting is basically firm's information on its social initiatives and their impacts - good or bad, on the society. Thus, the purpose of sustainability disclosure or corporate social reporting is "to establish and communicate the social impacts of business actions on those who are affected by them" (Sethi, 2013). Finally, the financial sector has woken up to various non-financial issues such as CSR/CSD/SD. Nonfinancial reporting, in fact, is an appropriate opportunity for the firm to communicate with its stakeholders in an open or transparent way . In these reports, firms provide information related to the social and environmental impacts of its activities during the year gone by, on their own i.e. without any compulsion or mandatory requirement. Such information or reports contributes to company's increased acceptability and competitiveness. For overall assessment of the company's profile, the non-financial disclosure is thus steadily gaining ground and plays an increasingly important role in the overall assessment of an organization.

During the recent past, especially since the turn of the century, sustainability reporting has been receiving unprecedented attention by the management. It has also been at the center of research sphere for a large number of analysis and investigations from different perspectives. The fast changing global business environment is indeed challenging or 
compelling corporate world to change their outlook and go beyond financial performance to for sustainable business. The need for strategic integration of social and environmental issues within the core business domain of the firm is increasingly realized by leaders of the industry all over the world. In a fast changing world of expectations, firms must be accountable for and responsible to their impact on society and environments within which they operate. Some of the key concerns for the society are climate change; degradation of environment, health \& sanitation, education; gender equality; community development and business sustainability among other pressing issues. And thus the importance, for an accurate and transparent accounting for and reporting of these activities in this age of real-time communication.

The reporting of social impact of business initiatives is still at an early stage in India as can be seen from the number of companies with nearly 125 , choosing to disclose their sustainability performance last year. Notwithstanding the dismal beginning, the industry is affirmative in embracing the concept and practice of corporate social reporting. In addition, the policy developments like National Voluntary Guidelines (NVGs) on Social, Environmental and Economical Responsibilities of Business will help boost the efforts of the companies in reporting on such issues in India. However, for India, reasons for embracing this concept differs when compared with other countries of the world where (in India) ethical considerations and idea of enhancing company reputation and brand precedes economic considerations, cost reduction or savings, innovation and employee motivation considered key business drivers globally for corporate to adopt sustainability reporting. This highlights the difference in perceptions and the fact that sustainability has not yet been integrated into the mainstream business strategy and operations in India whereas at international levels - amongst large, multinational corporations, sustainability reporting has become a mainstream activity. Notwithstanding the said fact, sustainability disclosure or CSR reporting in India has been at the center of focus and gaining ground in the recent past leading to a paradigm shift in corporate reporting culture.

"Fifteen years ago, it might have been enough to tick the boxes on accident frequency, employee satisfaction and heart-warming stories of philanthropic activities. However, this approach no longer cuts it when it comes to showing why sustainability matters and what level of performance an organization has achieved".

\section{- WBCSD, Reporting Matters (2013)}

Sustainability Reporting: Corporate Social Reporting or Sustainability Reporting (SR) has developed after Howard Bowen's "Social Responsibilities of Businessmen" was published in 1953, but in western world, particularly in the US - both as a concept \& theory and in practice. Social reporting essentially pertains to accounting as a rational assessment of certain purposive, meaningful, and definable domain of a business activities having a direct bearing or impact on society and its reporting. The main aim of social reporting is to measure both positive and negative effects of CSR initiatives on the enterprise itself as well as on its stakeholders, especially the society or immediate community. Social reporting is thus concerned with both internal and external assessment or measurement and reporting of information in non-financial terms about the impact of various business activities on society.

The relation between an enterprise and the society pertains to the use of social resources. The result is 'social cost' in case of over utilization or depletion of social resources on account of business activities whereas the same may result into 'social benefit' if there is an increase in social resources. According to Chen (1975), "as a steward, management's responsibility should be evaluated in terms of both profit and accomplishment of social objectives". Also, as observed by the committee of the American Institute of Certified Public Accountants (USA) "an objective of financial statement is to report on those activities of the enterprise affecting society, which can be determined and described or measured and which 
are important to the role of the enterprise in its social environment". In France, the disclosure of social responsibilities and their audit had been made mandatory for the companies several decades ago.

The practice of corporate social reporting in India has been in existence for long, almost parallel to the developed countries but as a voluntary exercise and without any mandatory rules or regulations for companies till the amendment in Company Act through Section 135 in 2013. Before this amendment, 'MAOCAR Order' introduced by the Government in 1975 and amended in 1988 was in operation. But it had no mention of any socio-economic activities to be undertaken by the companies and/or the need for auditors to mention its compliance in their annual reports. However, four decades back i.e. in 1978, Sachar Committee recommended that "a provision may be included in the Companies Act to make it obligatory for companies to give a social report along with the director's report, which would provide with a clear and quantified account of the social operations undertaken during the previous year". The ICAI, based upon a survey conducted in 1991, found that "123 out of 202 companies provided some information in their director's report about the company's contribution in the sphere of social responsibility". However, there was a steady change in the trend during last decade of $20^{\text {th }}$ and first decade of the $21^{\text {st }}$ century whereas the second decade has witnessed a kind of transformation in the nonfinancial reporting (Kulkarni, 2014) by organisations in the country.

The key issue before all stakeholders of a business enterprise is the need for transparency in and proactive communication of CSR activities. The growing demand for CSR reporting is the result of public concern for accurate information before forming an opinion about an enterprise - whether or not the firm is fair and proper, for evaluating its corporate legitimacy. A large number of corporate disclose social information on their own volition i.e. on voluntary basis. "These disclosures may take the form of management discussion in annual reports, or separate disclosure, social, sustainability or environmental report" (KPMG, 2005). However, the format, content or details on social disclosures have neither any uniformity nor regulated. The analysis and examinations of annual reports of firms forms the basis for numerous studies on the subject of CSR in general and in the area of corporate social disclosure in particular. And many of these studies measure the extent of disclosure or discover the relationship, if any, between corporate disclosure and other variables of interest by using content analysis and/or disclosure indices.

Elaborate guidelines have been issued for preparation of social or sustainability reports by some of the institutions like the Global Reporting Initiative (GRI) which are being used as a framework by many organizations to prepare their social reports throughout the world. The guidelines developed by GRI provide a systematic framework for sustainability reporting by organisations on TBL (Triple-Bottom-Line) performance i.e. on SEE (Social, Economic, and Environmental) dimensions of sustainability.

"Integrated reporting reflects a critical point in the evolution of financial accounting practice. Its core purpose is to ensure that organizations provide a more accurate account of their creation or destruction of value among the different forms of capital. It achieves this by shifting the focus away from the traditional exclusivity of financial measurement."

\section{-Dr. Robert Massie (Co-founder), GRI}

\section{Benefits of Sustainability Reporting}

Corporate Social Disclosure (CSD) or Sustainability Reporting (SR) is beneficial to the company in more than one way i.e. it not only helps in improving the internal processes but also impact the external perceptions. Reporting on aspects of environment, society and governance (ESG) leads to, beside improving internal processes and external 
perceptions, saving of money, reduction in environmental impacts, and consequently win business or attract customers having 'green' or 'sustainable' procurement principles.

Some of the important benefits a company can draw from sustainability reporting are:

- Improved learning and innovation at work

- Enhanced societal competition and reputation

- Increased competitive differentiation

- Increased business opportunities

- Improved business efficiency

- Improved transparency at corporate level

- Improved assessment of risks and opportunities

- Balanced or even assessment by stakeholders

- Increased engagement of stakeholders

- Increased engagement and attraction of talent

- Increased acceptability and competitiveness

- Improved communication amongst all concerned

- Integrated annual financial reporting

\section{RECOMMENDATIONS AND CONCLUSIONS}

The role and importance of Corporate Social Responsibility (CSR) is not only increasing with each passing day but also it occupies the central space within the development sphere all over the world today and provides an alternative avenue for sustainable development. It would not be an exaggeration to say that in today's business scenario, CSR is the fulcrum around which the whole wheel of development revolves and thus needless to reiterate - CSR plays a pivotal role in a firm's initiatives for social and sustainable development. The growing corporate's concerns for their stakeholders including the immediate community within which they exist \& operate clearly convey that society is immensely impacted by the corporate's activities and its fate is largely decided by them. CSR and SD initiative have proved to be widely effective all over the world - across economy and markets. Its influence is especially experienced among the developing economy and emerging markets.

The process of Sustainable Development (SD) or Corporate Sustainability (CS) is an ever evolving and shall remain as a mean and not an end whereas the corporate sustainability reporting is a complex and competitive set of principles, processes and procedures. "The GRI guidelines provide a well-established framework, including for companies that had developed their own tools" (Hohnen, 2012).

In India, though CSR has been in existence for long in one form or the other, with a rich history of charity \& philanthropy which is all the more prevalent today in the form of a firm's foundation, yet the CSR Act came into being 
with effect from $01^{\text {st }}$ April 2014 through an amendment in the Companies Act. Over five years on, CSR has not only dominated the discussions \& discourses at national level but has also been imbibed by the business making it an integral part of corporate's business strategy. Corporates are either directly undertaking or funding \& supporting social causes leading to a spectrum of developmental activities with a positive change in the society. Through such activities, corporates are participating in socio-economic-techno (SET) development of the country and thus complementing \& supplementing the efforts of the Government and non-profits (NGOs). The identification of the cause and taking it up on long term basis by the corporate will define the result of their involvement in sustainable development of the country and in order to achieve this, corporates need to formulate their CSR strategy keeping in view that a social cause or problem need to be addressed and solved in a holistic way rather than concentrating on just meeting CSR requirements in terms of the Companies Act, 2013. With an ever increasing demand for transparency and accountability, corporate will be required to adopt and implement the practice of detailed disclosures or reporting on their CSR strategy and its societal impact which can as well be used for making an informed business decision. In the years to come, reporting shall be taking us for a totally new experience i.e. the digital dialogue (as the authors call it) wherein 'story-telling' shall be an important attribute to underscore an effect or to highlight the impact.

\section{REFERENCES}

1. Amaeshi, K., Adi, A. B. C., Ogbechie, C., \& Amao, O. O. (2006). Corporate social responsibility in Nigeria: Western Mimicry or Indigenous Influences?

2. Branco, M. C., \& Rodrigues, L. L. (2006). Corporate social responsibility and resource-based perspectives. Journal of business Ethics, 69(2), 111-132.

3. Bowen, H. R. (2013). Social responsibilities of the businessman. University of Iowa Press.

4. Branco, M. C., \& Rodrigues, L. L. (2006). Corporate social responsibility and resource-based perspectives. Journal of business Ethics, 69(2), 111-132.

5. Carroll, A. B. (2016). Carroll's pyramid of CSR: taking another look. International journal of corporate social responsibility, $1(1), 3$.

6. Chen, R. S. (1975). Social and financial stewardship. The Accounting Review, 50(3), 533.

7. Dartey-Baah, K., Amponsah-Tawiah, K., \& Agbeibor, V. (2015). Corporate social responsibility in Ghana's national development. Africa today, 62(2), 71-92.

8. Fauset, C. (2006). What's wrong with corporate social responsibility. Corporate Watch Report, 2006, 8.

9. Hohnen, P. (2012). The future of sustainability reporting. EEDP Programme Paper. Chatham House, London.

10. Howard, B. (1953). Social responsibilities of the businessman. New York, Happer \& Brothers.

11. KPMG. (2005). KPMG International Survey of Corporate Responsibility Reporting 2005. Amsterdam, the Netherlands: KPMG Global Sustainability Services.

12. Kitzmueller, M., \& Shimshack, J. (2012). Economic perspectives on corporate social responsibility. Journal of Economic Literature, 50(1), 51-84.

13. Kulkarni, A. R. (2014). A review of concept and reporting of non-financial initiatives of business organisations. Procedia Economics and Finance, 11, 33-41. 
14. Kumar, K. V., \& Devi, V. R. (2015). Sustainability reporting practices in India: Challenges and prospects. In Twelfth AIMS International Conference on Management. Kozhikode: IIM.

15. OECD, O. (2004). The OECD principles of corporate governance. Contaduría y Administración, (216).

16. Sethi, P. (2013). Social Reporting by Indian Banks and Foreign Banks-A Comparative Analysis. IOSR Journal of Business and Management, 15, 45-53.

17. Visser, W. (2006). Revisiting Carroll's CSR pyramid. Corporate citizenship in developing countries, 29-56. 
